\title{
Appendix: List of IDS Conference Papers on Rapid Rural Appraisal
}

Papers presented to the Workshop held at IDS on 26-27 October 1978

Barker, David, Bedford College, Regents Park, London NW1 4NS Appropriate methodology: an example using a traditional African board game to measure farmers' attitudes and environmental images

Belshaw, D. G. R., School of Development Studies, University of East Anglia, Norwich Village viability assessment procedures in Tanzania: decision-making with curtailed information requirements

Clay, Edward J., IDS Direct and indirect methods of observation in Rapid Rural Appraisal

Jackson, Cecile, Sattar Mandal and Ian Carruthers, Wye College, Ashford, Kent Notes on rapid land ownership and management studies

Longhurst, Richard, IDS Rural stratification and resource allocation: some thoughts on deriving most useful information in short periods of time

Richards, Paul, University College, Gower Street, London WC1E 6BT 'Geography is a bottle of Heineken lager beer'- how to be the most boring person in development planning and still get your facts wrong

Sandford, Stephen, Overseas Development Institute, 10-11 Percy Street, London W1P 0JB Some miscellaneous thoughts

Situations and trends with pastoral people and livestock

Swift, Jeremy, IDS Notes on Rapid Rural Appraisal in dry pastoral areas of West Africa

Wood, Geof, University of Bath, Bath BA2 7AY The epistemology of Rapid Rural Appraisal?

Papers presented to the Conference held at IDS on 4-7 December 1979

Abel, Nick and Michael Stocking, School of Development Studies, University of East Anglia, Norwich Rapid aerial survey techniques for rural areas

Bajracharya, Deepak, Science Policy Research Unit, University of Sussex, Brighton Firewood consumption in the Nepal hills: a comparison of the annual recall and the weekly recorded data

Barnett, Andrew, Science Policy Research Unit, University of Sussex, Brighton A personal view of the first IDS workshop

Bartlett, C. D. S. and J. E. Ikeorgu, International Institute of Tropical Agriculture, Ibadan, Nigeria Selecting innovations for small farmers

Belshaw, D. G. R., School of Development Studies, University of East Anglia, Norwich Theoretical foundations of dataeconomising appraisal procedures, with applications to rural development planning

Biggs, Stephen D., IDS Timely analysis in programmes to generate agricultural technologies
Boxall, R. A., Tropical Products Institute, London Road, Slough SL3 7HL The use of Rapid Appraisal methods in the assessment of post-harvest losses

Bridger, G. A., Overseas Development Administration, Eland House, Stag Place, London Rapid Project Appraisal; original July 1977

Carruthers, Ian, Wye College, Ashford, Kent A mental construct for unstructured on-farm interviews

Breadth, depth or replications? $\rightarrow$ sampling problems with insufficient time, money or background

Too late to change. The reality of multidisciplinary planning in irrigation

Chambers, Robert, IDS Rural development tourism: poverty unperceived

Clay, Edward, J., IDS Farm management studies and the decision process; extract from 'Information and Research Inputs into Agricultural Policy Formation', Ministry of Agriculture and Forests, Dacca, September 1979

Collinson, Michael, CIMMYT, P.O. Box 25171, Nairobi, Kenya Understanding small farmers

Conlin, Sean, Land Resources Development Centre, Tolworth Tower, Surbiton, Surrey Baseline surveys: an escape from thinking about research problems and, even more, a refuge from actually doing anything

Ellman, Antony, Commonwealth Secretariat, Marlborough House, Pall Mall, London SW1Y 5HU Cost-effectiveness of Rapid Appraisal for rural project preparation

Eyben, Rosalind, UNDP, P.O. Box 913, Khartoum, Sudan Rapid Appraisal in non-formal education: an account of an on-going research experience with a United Nations project

Fallon, Peter, School of European Studies, University of Sussex, Brighton Comments on Mick Moore's 'Denounce the Gang of Statisticians, etc'

Feuerstein, Marie Therese, 49 Hornton Street, London W8 Establishing rapport; an informal paper for discussion

Gordon, Gill, IDS Finding out about child (0-5 years) feeding practices

The hungry season in the Savanna of West Africa

Hay, Roger, W., Queen Elizabeth House, Oxford Towards a methodology of 'Rapid Rural Assessment'? or can dirty methods be made cleaner?; an informal paper for discussion

Hildebrand, Peter E., University of Florida, Institute of Food and Agricultural Sciences, Gainesville, Florida, 32611, USA Summary of the Sondeo methodology used by ICTA

Comments about multidisciplinary team efforts. This paper originally appeared as an appendix to Peter E. Hildebrand 'Motivating Small Farmers to Accept Change'. Paper for the conference on Integrated Crop and Animal Production to Optimise Resource Utilisation on Small Farms in Developing Countries. Bellagio, 18-23 October 1978. The references are those of the original paper. 
Honadle, George, Development Alternatives Inc. 1823 Jefferson Place, NW, W ashington DC 20036, USA Rapid reconnaissance approaches to organisational analysis for development administration

Howell, John, Overseas Development Insititute, 10-11 Percy Street, London W1P 0JB Appraising organisations: purpose, method and cost-effectiveness

Howes, Mick, IDS Stratifying a rural population: trade-offs between accuracy and time

Longhurst, Richard, IDS Assessing economic stratification in rural communities

Moore, Mick, IDS Beyond the tarmac road: a (nut) shell guide for rural poverty watchers

Denounce the Gang of Statisticians. Struggle against the sample line. Unite the researching masses against professional hegemony

OXFAM Field Directors' Handbook: Three appendices: what to look for when visiting projects. Checklist on aspects of the participation of women in development projects. Social surveys

OXFAM, 274 Banbury Road, Oxford

Pacey, Arnold, 53 Millway Close, Upper Wolvercote, Oxford Rural Appraisal in sanitation programmes: a technology case-study

Payne, Philip, R., London School of Hygiene and Tropical Medicine, Keppel Street, London WCIE 7HT Assessment of nutrition problems: who do we look at and what do we measure?

Richards, Paul, University College, Gower Street, London WC1E6BT Appraising Appraisal

Stares, Rodney, OXFAM, 274 Banbury Road, Oxford Rapid Rural Appraisal and the needs of a non-governmental development agency: some thoughts from OXFAM

Stern, Peter, H., Intermediate Technology Development Group, 9 King Street, London WC2E 8HN Small-scale technology in water resources development

Stocking, Michael and Nick Abel, School of Development Studies, University of East Anglia, Norwich Ecological and environmental indicators for the Rapid Appraisal of natural resources

Taylor, Alan J., 17a South Street, Ditchling, Hassocks, W Sussex From Nicaragua: experiences with a model for assessing small scale rural development projects

Walker, Godfrey, London School of Hygiene and Tropical Medicine, Keppel Street, London WC1E 7HT Notes on rapid appraisal of the utilisation of rural health care services

Wood, Geof D., University of Bath, Bath, BA2 7AY The social and scientific context of RRA

\section{Papers tabled}

Chen, Lincoln C., Alauddin K.M.A. Chowdhury, Sandi Huffman, International Centre for Diarrhoeal Disease Research, Dacca, Bangladesh Classification of energyprotein malnutrition by anthropometry and subsequent risk of mortality

OXFAM Field Directors' Handbook: section 8: project design and assessment. The Handbook is a very substantially revised third edition of approx. $450 \mathrm{pp}$. with a complete set of guidelines covering the full range of development activities for OXFAM, including agriculture, health, and social development, also welfare and disaster relief.

OXFAM, 274 Banbury Road, Oxford

WHO, Selected health and health-related socio-economic indicators for measuring health status and evaluating health care

Interregional meeting on the development of health programme evaluation, Geneva, 9-14 July 1979

WHO, Regional Office for Africa Rapid village nutrition survey technique

\section{Papers subsequent to the Conference}

Chambers, Robert, IDS Shortcut methods in information gathering for rural development projects, paper for World Bank Agricultural Sector Symposia, January 1980

Conlin, Sean and Steve Wiggins, Land Resources Development Centre, Tolworth Tower, Surbiton, Surrey Rapid Rural Appraisal: a review of the December 1979 Conference and its papers 